\title{
Assessing the Influence of Corporate Social Responsibility on Organizational Image in Selected Food and Beverage Companies in Nigeria
}

\author{
Umar Abbas Ibrahim*, Alfa Abubakar \\ Department of Business Administration, Nile University of Nigeria, Abuja, Nigeria \\ Email address: \\ abbas.ibrahim@nileuniversity.edu.ng (U.A. Ibrahim), aalfa@marketbridge.ng (A. Abubakar) \\ ${ }^{*}$ Corresponding author
}

\section{To cite this article:}

Umar Abbas Ibrahim, Alfa Abubakar. Assessing the Influence of Corporate Social Responsibility on Organizational Image in Selected Food and Beverage Companies in Nigeria. Science Journal of Business and Management. Vol. 8, No. 1, 2020, pp. 27-34.

doi: $10.11648 /$ j.sjbm.20200801.14

Received: January 12, 2020; Accepted: January 31, 2020; Published: February 11, 2020

\begin{abstract}
This study portrays Corporate Social Responsibility (CSR) as an organizational activity whose successful planning and implementation can be used to gain positive Organizational Image (OI). The benefits of CSR to stakeholders have been well documented to a great extent. However, to the best of our knowledge, not much information is available on how CSR impacts the image of the organizations that render it. In an attempt to fill the gap, this study examined the impact of CSR on OI of selected companies in the food and beverage (F \& B) industry in Nigeria, looked at how organizational image influences Sales Revenue and explored the impact of organizational image on brand loyalty. The study employed survey research design and covered the Federal Capital Territory. A sample size of 180 was chosen from amongst dealers and bakers in the territory through Random Sampling Technique. A self-administered questionnaire was used for data collection from some customers of Flour Mills of Nigeria Plc which is the leading wheat flour millers in Nigeria in terms of production capacity. Data collected were analyzed using Statistical Package for Social Sciences (SPSS). Findings of the study revealed that CSR activities are prime drivers of Organizational Image building. Most importantly, it was discovered that there is a positive relationship between Organizational Image, Sales Revenue and Brand Loyalty. Based on the findings, organizations can invest more resources into CSR activities as a deliberate means of building positive image, attracting more Sales Revenue and developing sustainable brand loyalty as a means to achieve their long term strategic goals.
\end{abstract}

Keywords: Brand Loyalty, Corporate Social Responsibility, Organizational Image, Sales Revenue

\section{Introduction}

This article's overall aim is to assess the influence of Corporate Social Responsibility on the Organizational image of some selected companies in the foods and beverage industry in Nigeria. The purpose of the study is to integrate both primary and secondary research to understand the nature of corporate social responsibility (CSR) and its relationship with organizational image. CSR is defined as the actions carried out by companies positively influencing society where they perform their economic activities. The concept of CSR varies, as some firms designate it as: Corporate Social Responsiveness, Corporate Citizenship, Ethical Business Practices and Stakeholder Management [1]. The socioeconomic model of CSR is used as a basis for this research's theoretical framework for examining the CSR practices in the Nigerian business environment. Proponents of this model believe that businesses have a responsibility not only to their shareholders but also to stakeholders including customers, employees, suppliers, the government and general public. This school of thought recognizes the fact that businesses operate in society and that their activities impacts the society. A company has social responsibilities and is ethically responsible for its actions, because its strategic decisions often affect other stakeholders [2].

In recent years, CSR has become a widely and frequently debated topic in the Nigerian academic community given the effects that business-environment activities have on 
employees, clients, authorities, society, business partners, investors, and local communities. Organizational image is an important asset as it provides basis for stakeholders to favour an organisation. As a result of this, companies are more and more aware of the fact that they must accept the responsibility regarding the impact of their business activities on all the stakeholders and support, through voluntary actions, the communities where they perform their economic activities. A study conducted in Nigeria by Ayanda et. al. displayed that CSR is now crucial in creating attractive Organizational Image, providing competitive advantage and differentiation leading to business success [3]. Similarly, in his research Fadun opined that Nigerian consumers considered economic responsibility the most essential CSR dimension. With current estimated population of about 206 million people in Nigeria, over 63 percent of this number is of the millennial generation (Generation Y). They dominate the workforce and consumer market [2]. According to Spencer previously, price and quality completely dominate the buying decision of consumers, but in this era, millennial consumers are said to be more careful, cautious and educated about where and with whom they spend their hard-earned money [4]. Increasingly, organizations are flaunting their corporate social responsibility activities, which enhance organizational image; this in turn, elicits positive public perceptions [5].

Owing to its market size and potential, the number of competing enterprises in Nigeria is increasing. In the foods and beverage industry, companies attract customers through promotional activities such as Advertising and Public Relations. Hence, how to achieve and maintain a savory image is an important issue. Shu-Ling Hsu opined that companies must establish their Organizational Image to stabilize their market position [6]. To the best of our knowledge no previous research has studied how companies' CSR activities in the food and beverage industry influence their Organizational Image using Customer Patronage and Brand Loyalty as variables. By determining the relationship between these variables, companies and marketers can effectively craft their CSR strategies to entice consumers toward their brands. This contribution would further assist future efforts on the subject, especially in similar developing economies that share common characteristics with Nigeria.

\section{Concept of Corporate Social Responsibility}

Depending on the attitude of management, the nature of a business' social responsibility might take either of the two competing schools of thoughts or models - the economic model or the socioeconomic model. The economic model of CSR believes that a business exists solely to respond to market demand, produce quality products based on the demand, and generate profits. Accordingly, this school of thought argues that society will ultimately benefit from the success of a business organisation. It further holds that maximum social benefit will transpire only if businesses are free to produce and market products that the society needs. Nobel Prize-winning economist Milton Friedman introduced the Friedman doctrine of social responsibility in his 1962 book "Capitalism and Freedom" and in "A Friedman doctrine". He argued that the sole social responsibility of a corporation is to uphold the interest of the shareholders by maximizing profitability while also remaining obedient to the laws of the jurisdictions in which it operates. According to Friedman, responsibility that extends unto the community defeats the purpose of a free-market economy. He believes totalitarianism transpires when businesses concern themselves with the community rather than profitability. This model nonetheless argues that social responsibility is the job of others - mainly the government, non-profit organizations, and other social institutions. It believes that it would be unfair for shareholders to have their invested money channeled to expenditures that would not yield returns. Furthermore, this model also argues that businesses are already paying taxes and the government used these payments to meet the needs of the society. This means that successful businesses are indirectly fulfilling their social responsibility through taxation $[7,8]$.

On the other hand, proponents of the socioeconomic model of corporate social responsibility believes that businesses have a responsibility not only to shareholders but also to stakeholders including customers, employees, suppliers, and the public. This school of thought recognizes the fact that the operation of a business has an impact on the society. It also argues that business organizations should always consider this impact when making business decisions. American philosopher and business management Professor Freeman introduced the Stakeholder Theory in his 1984 book "Strategic Management: A Stakeholder Approach" to provide a groundwork for addressing the moral obligations of a business organisation. The theory holds that apart from shareholders, a business has a responsibility to promote the interests of varied parties: from employees, suppliers, and customers, to the government, community, and trade organizations [9]. Porter and Kramer also introduced the concept of creating shared value. In their initial article "Strategy \& Society: The Link between Competitive Advantage and Corporate Social Responsibility" followed by the related article "Creating Shared Value: Redefining Capitalism and the Role of the Corporation in Society" both published in the Harvard Business Review. The two argued that the competitiveness of a business organisation and the health of the community it serves are mutually dependent. Recognizing and capitalizing on this association creates a win-win situation for both a business and the society [10].

The socioeconomic model of corporate social responsibility is presently more popular amongst organizations for varied reasons. For public corporations for example, there is a strong requirement to become social responsible to promote and maintain an ideal public image. Funding from these corporations after all comes from the public. Another reason is that it would be in the best interest 
of businesses to be socially responsible because of the current business and legal landscapes. Doing so would help them avert problems arising from legal actions that might come from their stakeholders. An equally interesting reason is that companies are now taking corporate social responsibility seriously because they believe it is their way of giving back to the society. Hence, they take part in stakeholders' programs. This model of social responsibility is more acceptable in Nigeria. It shall be the focus of this study. Nigerian wheat milling sub sector of the F \& B industry is dominated by two major players; Flour Mill of Nigeria Plc (FMN) group and Crown Flour Mill group. Together they control about 79 percent of production capacity. However, only FMN is publicly quoted on the Nigeria Stock Exchange. [11]

The main objectives of this study are: to assess the influence of corporate social responsibility on organizational image; examine how organizational image influences Sales Revenue and to understand how organizational image influences brand loyalty. Hence, the study will attempt to provide answers to the three important questions: To what extent does corporate social responsibility influence organizational image of companies in the Foods and Beverage industry in Nigeria, is there any relationship between organizational image and Sales Revenue and does organizational image impact brand loyalty? Several studies have been made on how corporate social responsibility influences organizational image in Nigeria. However, to the best of our knowledge, research in this area in the food and beverage industry is nascent. This study is significant in a number of fronts; obtaining insight on how CSR impacts organizational image will aid understanding of how this practice can be used to build and sustain positive corporate image, increase Sales Revenue and build brand loyalty by more manufacturing organizations. The Nigerian economy, public, scholars and future researchers are also expected to benefit from this work.

CSR can be conceptualized through several view points. However, a three dimensional framework captures the main features of CSR. They are: human responsibility; environmental responsibility; and product responsibility [12]. Hence, it is widely accepted that CSR is a multidimensional concept and CSR initiatives are oriented towards various stakeholder groups like customers, employees, investors, regulators, the community or the environment. Societal expectations about the positive contributions from corporations are not a new phenomenon as the history of CSR dates back many centuries. CSR developed as a result of the interaction between industrialisation and globalisation. As industrialisation grew, corporations were criticised for advocating factory labour. The factory labour system required many work hours and that workers live far away from home which had a negative impact on family and the community. To counter this criticism, corporations developed "industrial welfare program which provided for the education, recreation and socialisation" of factory workers. Shortly after World War 1, Howard Bowen came up with what would become one of the earliest conceptions of CSR. He suggested at the time that "we are entering a time when private business will be judged solely in terms of its demonstrable contribution to general welfare". As far as he was concerned, it was the responsibility of business to ensure better standards of living, economic growth, security and freedom [13].

CSR is defined by the World Council for Sustainable Development as "the continuing commitment by business to behave ethically and contribute to economic development while improving the quality of life of the workforce and their families as well as of the local community and society at large" [14]. CSR activities lead to positive attributions from stakeholders, who then temper their negative judgments and sanctions toward firms because of this goodwill [15]. Similarly, following the European Commission definition, CSR is understood as the voluntary integration of social and environmental concerns in the enterprises' daily business operations and in the interaction with their stakeholders [16]. CSR is an essential element in building and maintaining favourable corporate reputation, which is regarded as an important strategic resource factoring into a company's competitive advantage [17]. Research by Khojastehpour and Johns opined that CSR is used to describe how businesses implement the broad societal responsibility of going beyond economic criteria. They found that CSR issues may benefit organizations in building their reputation and suggested that customers expect firms to be involved in CSR activities and may reward them for their efforts [18].

\subsection{Concept of Organizational Image}

According to Lievens in his article Organizational image/reputation, organizational image refers to people's global impressions of an organization and is defined as people's loose structures of knowledge and beliefs about an organization. It represents the net cognitive reactions and associations of customers, investors, employees and applicants to an organization's name. Accordingly, it serves as a template to categorize, store, and recall organizationrelated information. He opined that there is no such thing as "the" organization's image, because an organization typically has multiple images depending on its various stakeholders or corporate audiences. Different stakeholders hold different images of the same organization. For instance investors and executives hold an image of an organization as an economic performer ("company financial image"). They typically rely on factual economic figures as a basis of their beliefs about the organization. Similarly, there is the image of an organization as a social performer in the general society ("corporate social performance"), which can be further broken down into an organization's involvement in the community and its pro-environmental practices. In the same vein, customers or clients hold an image of an organization as a provider of goods and services ("product image or service image"). Also, each organization has an image as an employer among current employees and (potential) applicants (employer image) [19]. 
Organizational images are formed over long periods of time. They are derived from, among other things, media coverage, individual or group interactions with the organization, and communication on the part of the organization (as reflected in its advertising, sponsorships, and publicity). It is worthy of note that organizational images are not static. In fact, nowadays proactive organizations often audit their images. In these image audits, the aim is to carefully determine which factors make up the image among various stakeholders. Next, organizations aim to strategically modify the image held by these stakeholders. For instance, this might be done by increasing an organizations exposure or by highlighting specific attributes in advertising campaigns [19]. Organizational image is by definition difficult to imitate and it creates responsibilities such as obligations to meet the personal standards of the employees, the quality standards of customers, the ethical standards of the community and the profitability standards of investors. As people tend to humanize companies, corporate image involves characteristics traditionally attributed to humans. People, indeed, seek cues to guide them towards behaviors to gain social acceptance, necessary condition for a sense of personal and group validity [20]. In their research titled "Marketing strategy and product performance: a study of selected firms in Nigeria" Banjo, Obasan and Ariyo found that Marketers and organizational managers are interested in managing their organizations to achieve surplus (profit) which is often used as the greatest yardstick for organizational performance. Marketers in particular, in doing this, manipulate the marketing mix to stimulate exchange between the firm and customers. However, in the recent times, attention has been on brand loyalty [21].

\subsubsection{Dimensions of Image}

Lievens' definition of organizational image reflects a holistic view of the subject. Several other views abound on the term. This study is to view organizational image from the standpoint of Sales Revenue and Brand Loyalty. In the manufacturing sector, Sales Revenue is the income received by an organization from its Sales Revenue of goods in the normal operations of business. It is calculated by multiplying the number of units sold or produced by the average Sales Revenue price per unit of an item over a period of time. The terms "Sales Revenue" and "revenue" can be, and often are, used interchangeably, to mean the same thing. It is important to note that revenue does not necessarily mean cash received. A portion of Sales Revenue may be paid in cash and a portion may be paid on credit, through means such as accounts receivables. It is the very first line of the income statement and is also known as the "top line". Organizations often strive to maximize their Sales Revenue through customer's patronage concentration which is the share of an individual consumer's expenditures in an industry or retail sector that is spent at one company. The goal of many firms is to increase the patronage concentration ratio of its customers to $100 \%$. In order to achieve this, modern organizations often try to understand the underlying factors behind customers' buying motives and explore them to their advantages. Buying motives are those motives of consumer's which are sufficiently stimulated so as to induce the consumer to buy the product. These are the needs, which are pressing needs, causing anxiety and restlessness to the customers, so much so that the consumer has to make efforts to buy a suitable product. This is supported by Ayanda, and Baruwa, who posited that Corporate Social Responsibility is now crucial in creating attractive Organizational Image, providing competitive advantage and differentiation leading to business success [3].

\subsubsection{Brand Loyalty}

The tendency of consumers to continuously purchase one brand's products over another. Consumer behavior patterns demonstrate that consumers will continue to buy products from a company that has fostered a trusting relationship. Brand loyalty defined as a positively biased tendency contains three distinct dimensions. The first dimension is the emotive tendency toward the brand. It refers to the affective (like-dislike), fear, respect or compliance tendency which is systematically manifested more in favor of a brand than other brands in the market place. The emotive tendencies are learned by the consumer either from prior experiences with the brand or from non experiential or informational services. The examples of emotive tendencies include the strong emotional stereotypes or brand imageries which researchers talk about as commonly prevalent among consumers. The second dimension of brand loyalty is the evaluative tendency toward the brand. It refers to the positively biased evaluation of the brand on a set of criteria which are relevant to define the brand's utility to the consumer. The evaluative tendency dimension of brand loyalty is also learned by the consumer either from prior experiences with the brand or from non experiential or informational sources. The third dimension of brand loyalty is the behavioral tendency towards the brand. It refers to the positively biased responses toward the brand with respect to its procurement, purchase and consumption activities. In short, it represents the time and motion study of the consumer as he behaves toward the brand in a positively biased way. The behavioral tendency is learned primarily from the experiences of buying and consuming the brand or from generalization of similar tendencies toward other brands. Recall that "corporate image is an important asset as it provides a basis for stakeholders to favour the organization; it also creates strategic advantages for the organization" [5].

\subsection{Theoretical Framework}

Stakeholder theory of corporate social responsibility outlined by Klaus in his book "Modern Enterprise Management in Mechanical Engineering", argues that the management of a modern enterprise must advance the interest of all its stakeholders in order to achieve long-term growth and prosperity [22]. In 1983 American professor R. Edward Freeman wrote an article on Stakeholder theory in the California Management Review. He followed this article 
with a book "Strategic Management: a Stakeholder Approach". This book identifies and models the groups which are stakeholders of a corporation, and both described and recommended methods by which management can give due regard to the interests of those groups. In short, it attempts to address the "principle of who or what really counts". Stakeholder theory posits that there are many parties involved, including employees, customers, suppliers, financiers, communities, governmental bodies, political groups, trade associations, and trade unions. Even competitors are sometimes counted as stakeholders - their status being derived from their capacity to affect the firm and other stakeholders. The nature of what constitutes a stakeholder is highly contested with hundreds of definitions existing in the academic literature [23]. According to Lin the stakeholder theory is a theory of organizational management and business ethics that accounts for multiple constituencies impacted by business entities like employees, suppliers, local communities, creditors, and others. It asserts that managers must satisfy a variety of constituents who can influence the firm's outcomes and addresses morals and values in managing an organization, such as those related to corporate social responsibility, market economy, and social contract theory [24].

\subsection{Empirical Review}

The results of global research by Edelman show that CSR is increasing in importance in the consumer decision making process. It is extremely important to emphasize that CSR is becoming more and more important in emerging markets [25]. Fatt, Wei, Yuen and Suan noted that consumer expectations and requirements have increased: consumers expect a company to be a citizen and a part of local community. $86 \%$ of consumers believe that CSR is as important as other business' everyday operations, two-third of consumers who partook in the research think that companies should support various societal and causal initiatives $[25,26]$. Socially responsible manner to conduct business should be the new business standard, as they stressed that socially responsible companies earn positive image in the society due to the fact that they gain more mass media attention and form positive employee attitude towards the company [27-32].

\section{Methodology}

This study employed Survey Research Design. It covers the food and beverage industry in Nigeria with focus on the wheat milling subsector. Case study was on Flour Mill of Nigeria Plc. The company is the oldest flour miller in the country, possesses $40 \%$ of the installed milling capacity in the industry and is presently the only one quoted on the Nigerian stock exchange. Data was sourced through field survey. The researchers used Questionnaire for data collection from the company's dealers and bakers resident within the Federal Capital Territory. A sample size of 180 was chosen through Random Sampling to give every dealer and baker equal chance of participation in the exercise. 180 questionnaires were distributed but only 154 returned duly completed. Data Analysis was achieved using Statistical Package for Social Sciences (SPSS). This is due to its suitability for estimation, forecast or prediction of relationships between independent and dependent variables. SPSS is also reliable for processing of primary data.

\section{Results and Analysis}

Descriptive Statistics

Table 1 below shows the descriptive statistics. It depicts the number of observations $(\mathrm{N})$, minimum, maximum, mean and standard deviation of the variables used.

Table 1. Descriptive Statistics.

\begin{tabular}{lllll}
\hline & N & Minimum & Maximum & Mean \\
\hline CSR & 154 & 1.00 & 5.00 & 1.7857 \\
Sales Revenue & 154 & 2.00 & 5.00 & 2.6234 \\
Stakeholders' Communication & 154 & 1.00 & 5.00 & 1.01598 \\
Organizational Image & 154 & 1.00 & 5.00 & .76763 \\
Valid N (list wise) & 154 & & .80170 & .7273 \\
\hline
\end{tabular}

Source: SPSS 20.0

Corporate Social Responsibility (CSR) has a Mean value of 1.7857 , with a standard deviation value of 1.01598 . It has a minimum and maximum value of 1.0 and 5.0 respectively. Sales Revenue has a Mean value of 2.6234; with a standard deviation value of .76763 . It has a minimum and maximum value of 2.0 and 5.0 respectively. Brand Loyalty has a Mean value of 1.8961 , with a standard deviation value of .80170 . It has a minimum and maximum value of 1.0 and 5.0 respectively. Organizational Image was tested with a mean value of 1.7273 and a standard deviation value of .99851 . It has a minimum and maximum value of 1.0 and 5.0 respectively.

Table 2. Variables.

\begin{tabular}{|c|c|c|c|c|c|}
\hline VARIABLES & & CSR & Sales Revenue & Brand Loyalty & Organizational Image \\
\hline \multirow{3}{*}{ CSR } & Correlation & 1.000 & .273 & .597 & .700 \\
\hline & Significance (2-tailed) & . & .001 & .000 & .000 \\
\hline & Df & 0 & 151 & 151 & 151 \\
\hline
\end{tabular}




\begin{tabular}{llllll}
\hline VARIABLES & & CSR & Sales Revenue & Brand Loyalty & Organizational Image \\
\hline \multirow{3}{*}{ Sales Revenue } & Correlation & .273 & 1.000 & .202 & .212 \\
& Significance (2-tailed) & .001 &. & .012 & .008 \\
& Df & 151 & 0 & 151 & 151 \\
\multirow{3}{*}{ Brand Loyalty } & Correlation & .597 & .202 & 1.000 & .599 \\
& Significance (2-tailed) & .000 & .012 &. & .000 \\
\multirow{5}{*}{ Organizational Image } & Df & 151 & 151 & 0 & 151 \\
& Correlation & .700 & .212 & .599 & 1.000 \\
& Significance (2-tailed) & .000 & .008 & .000 &. \\
& Df & 151 & 151 & 151 & 0 \\
\hline
\end{tabular}

The Table 2 shows the correlations between Corporate Social Responsibility and Organizational Image. It could be observed that Corporate Social Responsibility, Customer Patronage, and Brand Loyalty have positive correlations with Organizational Image. The correlation between Corporate Social Responsibility and Organizational Image is .700, between Corporate Social Responsibility and Sales Revenue is .273, and between Corporate Social Responsibility and Brand Loyalty is .597. This reveals that the correlation is not high between each of the variables. However, considering the significant level of the relationship, the correlation matrix table reveals that the variables maintain homogeneity in terms of significance among the variables. This will lead us to hypothesis testing to ascertain the level of significance of the association.

Hypotheses Testing

Decision rule: Reject the null hypothesis if the Sig. level (2-tailed) is lower than 0.05 significant levels.

Ho 1: There is no significant relationship between Corporate Social Responsibility and the Organizational Image

Table 3. Correlation between CSR and Organizational Image.

\begin{tabular}{lll}
\hline Variable & Coefficient & Sig-Value \\
\hline Corporate Social Responsibility & 0.700 & .000 \\
\hline
\end{tabular}

Source: Computed from Table 2

Result from the correlation matrix table above indicates that there is a positive effect of Corporate Social Responsibility on Organizational Image. This is evidenced by coefficient value of 0.700 . Statistically, the Sig. value of 0.000 is lower than the acceptable significance value of 0.05 . We therefore, reject the null hypothesis that there is no significant relationship between Corporate Social Responsibility and Organizational Image.

Ho 2: There is no significant relationship between Organizational image and Sales Revenue of its products.

Table 4. Correlation between CSR and Sales Revenue.

\begin{tabular}{lll}
\hline Variable & Coefficient & Sig- Value \\
\hline Sales Revenue & 0.273 & .000 \\
\hline
\end{tabular}

Source: Computed from Table 2

The result from the correlation matrix table above indicates that there is a positive relationship between Organizational Image and Customer Patronage. This is evidenced by coefficient value of 0.273 . Statistically, the Sig. value of 0.001 is lower than the acceptable significance value of 0.05 . This positive relationship was found to be significant. We therefore, reject the null hypothesis that there is no significant relationship between Organizational Image and Sales Revenue.

Ho 3: There is no significant impact of organizational image and brand loyalty.

Table 5. Correlation between CSR and Brand Loyalty.

\begin{tabular}{lll}
\hline Variable & Coefficient & Sig- Value \\
\hline Brand Loyalty & 0.597 & .000 \\
\hline
\end{tabular}

Source: Computed from Table 2

The result from the correlation matrix table above indicates that there is a positive relationship between Organizational Image and Brand Loyalty. This is evidenced by coefficient value of 0.597 . Statistically, the Sig. value of 0.000 is lower than the acceptable significance value of 0.05 . This positive relationship was found to be significant. We therefore, reject the null hypothesis that there is no significant impact of Organizational Image on Brand Loyalty.

\section{Discussion}

This research work aims to examine the impact of corporate social responsibility on organizational image in a food and beverage industry setting in order to support evidence that the effect of CSR as a tool for constructive engagement with stakeholders is far-reaching. Our findings have revealed that there is a positive and significant relationship between corporate social responsibility undertaken by companies and their organizational image. This is consistent with results of previous efforts in the field especially one by Bowen who posited that "we are entering a time when private business will be judged solely in terms of its demonstrable contribution to general welfare" [33]. The works of Ayanda and Baruwa which found that the image of a company as a good corporate citizen helps it to gain more Sales Revenue and brand loyalty as society accepts such a company as one of its own has also been validated by our findings [3]. Similarly, a research by Adeniji et. al. which reveals that there is a positive correlation between people's perceptions of a company and pro-corporate supportive behaviour is in agreement with the relationship established between organizational image and Sales Revenue [20]. The positive relationship between organizational image and brand 
loyalty also corroborates the findings of a research by Banjo, Obasan and Ariyo. Their findings revealed that there is a significant relationship between brand loyalty for a product and the level of profitability of the organisation owning that brand. In order words, the more consumers develop attachment to a brand measured as brand loyalty, the more the company becomes more profitable [21]. A few limitations need to be acknowledged. First, out of top two major flour mill groups in the country, only FMN was selected and used for the study while the other (Crown Flour Mill group) known for CSR was omitted as the company is a limited liability entity. Findings were limited in scope and future studies can extend to more quoted companies in other sub sectors of the F \& B industry. Second, the research was also conducted within a specific region in the country and as such these findings may or may not be generalized to other regions such as the southeast or the southwest. Third, the secondary data of the study did not include stakeholders other than dealers and bakers of the company, suggesting that further analysis of the model should be made using data from additional stakeholders.

\section{Conclusion}

A good number of previous studies indicated that CSR activities contribute to positive image building and business performance. They have shown evidence indicating that CSR practices affect the organizations' employee attitudes and behaviors, operational performance, societal sentiment in favor of an organization and shareholders' wealth maximization. This research has also found that CSR can be used by manufacturing organizations as a tool to build favorable image and utilize such positive image to enhance Sales Revenue and achieve brand loyalty for their products. This reinforces the stakeholder theory of CSR. It therefore, means that through the initiation and implementation of relevant CSR programmes, a company can acquire the necessary good image and attract more patronage and brand loyalty from its numerous stakeholders. Arising from the foregoing, we recommend that organizations endeavor to understand the nexus between their operations and the needs of various stakeholders in the societies in which they do business, select-mutually beneficial issues to address and invest their resources in initiatives that generate large and distinctive benefits for society in a way that add to the organizations' bottom line

\section{References}

[1] Kemper, J., Schilke, O., Reimann, M., Wang, X., \& Brettel, M. (2013). Competition-motivated corporate social responsibility. Journal of Business Research, 66, 1954-1963.

[2] Fadun, Olajide Solomon. (2014). Corporate Social Responsibility (CSR) Practices and Stakeholders Expectations: The Nigerian Perspectives. Research in Business and Management. 1. 13. 10.5296/rbm.v1i2.5500.
[3] Ayanda A. M and \& Baruwa A. A. (2014). Corporate Social Responsibility and Corporate Image, Transnational Journal of Science and Technology, 3 (8), 29-49.

[4] Michael S. Spencer (2017) Microaggressions and Social Work Practice, Education, and Research, Journal of Ethnic \& Cultural Diversity in Social Work, 26: 1-2, 1-5, DOI: 10.1080/15313204.2016.1268989.

[5] Pang, O. L. May, Chrystal, S. N. Ying-Kai, O. Shannon R. W. and Kristle P. Y. (2018). Utilization of CSR to build organizations' corporate image in Asia: need for an integrative approach, Asian Journal of Communication, 28 (4), 335-359.

[6] Shu-Ling, H. (2018). The Effects of Corporate Social Responsibility on Corporate Image, International Journal of Social Sciences and Humanities Invention, 5 (05): 4693-4703.

[7] Milton, F. (1962) The Social Responsibility of Business is to Increase its Profits, Colorado.edu. Retrieved 3 September 2017.

[8] Milton, F. (1970), A Friedman doctrine, Select.nytimes.com, Retrieved 3 September 2017 via NYTimes.com.

[9] Freeman, R. and Reed, D. L. (1984) Stockholders and Stakeholders: A New Perspective on Corporate Governance (California Management Review).

[10] Porter, M. E. and Kramer, M. R. (2006). Strategy and Society: The Link between Competitive Advantage and Corporate Social Responsibility. Harvard Business Review, 84, 78-85.

[11] Porter, M. E. (2011). Creating Shared Value: Redefining Capitalism and the Role of the Corporation in Society. Harvard Business Review, 89 (1/2), 62-77.

[12] Anselmsson, J. and Johanson, U. (2007). Corporate Social Responsibility and the positioning of grocery brands, International Journal of retail and Distribution Management, 35 (10), 835-856.

[13] May, S. K. Cheney G. and Roper J. (2007). The Debate over Corporate Social Responsibility Oxford University Press, 2007.

[14] Crane, A. Matten, D. and Spence, L. J. (2008). Corporate Social Responsibility in Global Context, Routledge, 2013.

[15] Godfrey, P. C. Merrill C. and Hansen, J. M. (2009). The Relationship between Corporate Social Responsibility and Shareholder Value, Strategic Management Journal, 30 (4), $425-445$.

[16] Benoît-Moreau, F. and Parguel, B. (2011). Building brand equity with Environmental Communication: An empirical investigation in France, EuroMed Journal of Business, 6 (1), 100-116.

[17] Park, J. and Lee, H. and Kim, C. (2014). Corporate social responsibilities, consumer trust and corporate reputation: South Korean consumers' perspectives, Journal of Business Research, 67 (3), 295-302.

[18] Khojastehpour, M. and Johns, R. (2014). The effect of environmental CSR issues on corporate/brand reputation and corporate profitability. European Business Review, 26 (4), 330-339.

[19] Lievens, F. (2017). Organizational image/reputation, Encyclopedia of Industrial and Organizational Psychology, Research Collection Lee Kong Chian School of Business, 1116-1118. 
[20] Adeniji, A. A. Osibanjo, A. O. Abiodun, A. Abolaji, J. and Oni-Ojo, E. E. (2015) Corporate Image: A Strategy for Enhancing Customer Loyalty and Profitability, Journal of South African Business Research, Vol. 2015.

[21] Banjo, H. Obasan, K. and Ariyo, O. (2015). Brand Loyalty and Organisational Profitability, Fountain Journal of Management and Social sciences. 4. 60-73.

[22] Klaus, S. (1971). Modern Enterprise Management in Mechanical Engineering, Verein Deutscher MaschinenbauAnstalten e. V. Frankfurt/Main-Niederrad.

[23] Miles, S. (2012). Stakeholders: essentially contested or just confused? Journal of Business Ethics, 108, 285-298.

[24] Lin, T. C. W. (2018). Incorporating Social Activism, Boston University Law Review, 1535, https://ssrn.com/abstract $=3294317$

[25] Edelman, D. (2010). Branding in the Digital Age: You're Spending Your Money in All the Wrong Places, Harvard Business Review, 88 (12), 62-69.

[26] Fatt, J. Wei, M. Yuen, S. and Suan, W. (2000). Enhancing corporate image in organizations, Management Research News, 23. 28-54. 10.1108/01409170010782037.
[27] Lizarraga, M. and Elawar, M. (2010). Looking at teacher identity through self-regulation. Psicothema, 22. 293-8.

[28] Askegaard, S. and Christensen, L. T. (2001). Corporate identity and organizational image revisited-A semiotic perspective, European Journal of Marketing, 35 (3-4), 292-315.

[29] Moir, L. (2001). What Do We Mean by Corporate Social Responsibility? Corporate Governance, $M C B$ University Press, 1472-0701 16.

[30] Chattananon, A. Lawley, M. Trimetsoontorn, J. Supparerkchaisakul, N. and Leelayouthayothin, L. (2003) Building Corporate Image through Societal Marketing Programs, Society and Business Review, Vol. 2 Iss 3 pp. 230253.

[31] Ailawadi, K. L. Luan, Y. J. Neslin, S. A. and Taylor, G. A. (2011). The Impact of Retailers' Corporate Social Responsibility on Price Fairness Perceptions and Loyalty, Institut d'economie industrielle.

[32] Green, T. and Peloza, J. (2011) How does Corporate Social Responsibility Create Value for Consumers? Journal of Consumer Marketing, 28 (1), 48-56.

[33] Bowen, H. R. (1953). Social responsibilities of the businessman. Harper, New York, 1953. 